\title{
En planta
}

\section{Plan view}

En medio de un panorama dominado por la cultura de las imágenes, donde la fotografía de arquitectura y el render se ban vuelto los medios de comunicación predilectos, volvemos por un minuto a detenernos en las plantas de arquitectura. Verdadera buella del edificio sobre el suelo, la planta contiene una parte importante de las claves del proyecto, siendo al mismo tiempo medio de representación, berramienta de diseño para el arquitecto, patrón de trazado e instrucción para el constructor. Aunque la planta se presenta invisible al habitante, ella determina con precisión la calidad de los espacios en que vivimos. Sin fotografías, vemos nuevamente en planta.

Palabras clave: Plantas de arquitectura, dibujos de arquitectura, representación, trazados, levantamientos.
In an age dominated by a culture of images when arcbitectural photography and rendering bave become the media of choice, we take a look back at the ground plan. A genuine footprint of a building on its site, the ground plan contains many of the key aspects of a project, at once a means of representation, an architect's design tool, and a layout and instruction pattern for the builder: Though the ground plan is invisible to the inhabitant, it determines with precision the quality of the spaces we in habit.

Without the photos, we see the plan view once again. Key words: Architectural ground plans, architectural drawings, representatation,
layouts, surveys. 


\section{Sobre la planta: retícula, formato, trazados Josep Quetglas}

Al iniciar el proyecto de la Villa Savoye, Le Corbusier y Pierre Jeanneret adoptan una malla estructural utilitaria, formada por una simple cuadrícula de tres módulos de lado, con una breve solapa lateral en voladizo a derecha e izquierda. Es, antes que un conjunto de dieciséis pilares, una simple pauta, una trama de líneas donde sostener las dimensiones y relaciones mutuas entre espacios y actividades. No hay que confundir esta retícula con una determinación constructiva, aunque la medida del módulo no sea arbitraria y coincida, por simple sensatez, con la crujía habitual en los proyectos del taller de esa época $-5 \mathrm{~m}$ entre ejes de pilares, con dos voladizos laterales de 1,25 m-.

Que la retícula así formada sea una cuadrícula, es decir, que todavía no se haya determinado la dirección del forjado, basta para indicar que se trata de un momento inicial, pre-constructivo. De hecho, cuando se determine el diseño estructural de la villa, la cuadrícula pasará, como en Les Terrasses, a ser rectangular y la estructura se
To begin their work on the Villa Savoye project, Le Corbusier and Pierre Jeanneret created a structural grid consisting of a simple series of three square modules side by side, with a short lateral overlap projecting out to the left and right. Rather than just a set of sixteen pillars, this useful device was a simple guide or pattern of lines on which to sustain the dimensions of the spaces and activities and their interrelationships. Though this reticle did not determine the dimensions of actual construction, the modules' measurements were not arbitrary and in fact were chosen to coincide, for purely practical reasons, with those of the bay commonly found in the workshop's projects of that era, which were $5 \mathrm{~m}$ between pillar axes with lateral overlaps of $1,25 \mathrm{~m}$. That the reticle so created was a series of squares, meaning that the direction of the beam framework had yet to be determined, demonstrates clearly that the process was still at a very early, preconstruction stage. Once the structural design of the villa had orientará según pórticos paralelos.

La superficie ocupada resulta de $17,5 \times 15 \mathrm{~m}$, es decir 262,5 $\mathrm{m}^{2}$ por planta. La superficie de Les Terrasses, ocupando un rectángulo de $20 \times 13,25$ $\mathrm{m}$, era de $265 \mathrm{~m}^{2}$; prácticamente igual, pese a que los Savoye fueran una pareja con un hijo mientras que el grupo familiar en Les Terrasses era más numeroso y, sobre todo, más complejo en sus relaciones internas. La heterogeneidad de la ocupación daba en Garches un ritmo alternado de $2-1-2-1-2$ por $0,5-1,5-1,5-1,5-0,5$, mientras que en Poissy es, simplemente, un compás regular de $0,5-2-2-2-0,5$ por $2-2-2$.

Se entiende mejor el carácter compositivo, no estructural, de esta trama de dibujo cuando se compara el rectángulo de la planta con el formato de las pinturas puristas de Jeanneret. Las pinturas están hechas habitualmente sobre una tela entre rectangular y cuadrada, de colocación tanto horizontal como vertical, en la que pueden inscribirse dos triángulos equiláteros iguales y opuestos, con el vértice de uno en el punto medio de la base del otro. Según Ozenfant y Jeanneret, ese esquema determina una proporción de la tela $\mathrm{y}$ unos puntos y ejes interiores capaces de sostener con precisión y asegurar la eficacia de las posiciones más comprometidas de la composición. been established, the squares became rectangular and the structure would be oriented as parallel porticos, as was the case with Les Terrasses.

The occupied surface area was $17,5 \mathrm{~m} \times 15 \mathrm{~m}$, or $262,5 \mathrm{~m}^{2}$ for each plan view. The area for Les Terrasses was $265 \mathrm{~m}^{2}$, or almost the same despite the fact that the Savoye family consisted only of a couple with one child while the family residing in Les Terrasses was more numerous and, more importantly, more complex in its internal relations. The heterogeneity of their occupation in Garches resulted in an alternating rhythm of $2-1-2-1-2$ by $0,5-1,5-1,5-1,5-0,5$, while at Poissy it was simply a regular rhythm of $0.5-2$ $2-2-0,5$ by $2-2-2$.

The compositional rather than structural character of this drawing pattern may be better understood if one compares the plan rectangle with the format of Jeanneret's purist paintings. The paintings were usually done on a rectangular canvas that was almost square, oriented both horizontally and vertically, on which two equal and opposite equilateral triangles could be drawn with the vertex of one at the midpoint of the base of the other. According to Ozenfant and Jeanneret, this arrangement yields canvas proportions and internal points and 

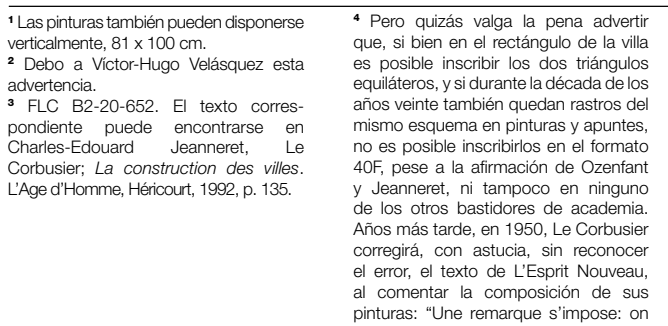

voit que les tracés ne partent pas des quatre coins de la tolle, mais qu'lls
laissent un résidu (...). L'exégéte non averti pourra s'évertuer sans succés à reconnaître en ces œuvres des touse parts des quatro cons de toile; ll ny arivera pas ou tombera les tracés régulateurs depuis plus de trente années, je déclare qu'une fois les années écoulées et la mémoire défaillie, il est très difficile de retrouver le véritable trace regulateur dans une ceurse remontant a dix ou trente annees, a des points de repère" (Le Corbusier,
Le Modulor, cit., pp. 214-215). Sobre estas cuestiones, vid: R. Fischler 1979. Fischler comenta que el formato $40 \mathrm{~F}$ puede ser considerado suma de dos rectangulos de proporciones aureas, lo habiean advertido zentant tampoco depender el cambio de actitud de Le Corbusier hacia la sección áurea de la lectura de Esthétique des Proportions, de Matyla Ghyka, publicado en 1927, pero los primeros trazados en su arquitectura no
verano de 1928.
"Es costumbre escoger bastante arbitrariamente el formato de la tela. Muchos pintores adoptan sin reflexión superficies muy alargadas, superficies fragmentarias que escapan a la visión normal del ojo. (...)

Nosotros hemos elegido las superficies similares a las de la tela de 40F, estimando que esta superficie es de orden indiferente. (...)

Además, esta superficie contiene propiedades geométricas importantes: permite diversos trazados que determinan lugares geométricos del mayor valor plástico. Estos trazados son los del triángulo equilátero, que se inscribe eficazmente en la tela, y que determinan en los ejes dos lugares del ángulo recto del mayor valor constructivo. La tela se encuentra asi dividida en segmentos con ángulos parecidos y contiene líneas que conducen al ojo hasta los puntos más sensibles. Estos puntos sensibles constituyen verdaderos centros estratégicos, orgánicos, de la composición" (Ozenfant y Jeanneret, 1921).

Se trata del formato de academia 40 Figura, equivalente a un bastidor de medidas $100 \times 81$ cm. En el número 17 de L'Esprit Nouveau (junio de 1922), se publica un ejemplo de trazados reguladores en una tela de Jeanneret y en otra de Ozenfant: la tela de Jeanneret muestra los dos triángulos invertidos.

axes that could precisely sustain and ensure the effectiveness of the most important positions of the composition.

"The canvas format is normally chosen quite arbitrarily. Many painters unthinkingly use very elongated formats that are fragmentary and escape the eye's normal field of vision.(...)

We have chosen sizes similar to those of a $40 \mathrm{~F}$ canvas, on the view that this format is of an indifferent order. (...) Furthermore, this format has important geometrical properties, allowing various lines to be traced that determine geometrical places of great plasticity. The lines are those of an equilateral triangle that can be usefully drawn on the canvas, creating two "places of the right angle" of great constructivity. The canvas is thus divided into segments of similar angles and contains lines that lead the eye to the most sensitive points. These sensitive points constitute genuine strategic and organic centers in the composition" (Ozenfant and Jeanneret, 1921).

The French $40 \mathrm{~F}$ format is equivalent to a $100 \mathrm{~cm}$ x $81 \mathrm{~cm}$ stretcher frame. Issue no. 17 of L'Esprit Nouveau (June 1922) contains an example of regulating lines on a canvas by Jeanneret and another by Ozenfant. Jeanneret's canvas shows
Si aceptamos el listado de pintura en Le Corbusier lui-même (Petit, 1970) como estadísticamente representativo, podemos contar que, entre 1919 y 1930, de 144 telas pintadas, 72 de ellas, exactamente un $50 \%$, han sido escogidas con el formato 40F: miden $100 \times 81 \mathrm{~cm}^{1}$.

Esa proporción de rectángulo en el que se inscriben los dos triángulos equiláteros es la misma de los que serán, desde 1929, los tomos de sus Euvres complètes ${ }^{2}$, y ya había sido conocida por Le Corbusier desde 1915, aplicada a la arquitectura, cuando, en sus sesiones en la Biblioteca Nacional, trabajando sobre lo que debía ser su libro La construction des villes, dibuja los "Parvis dorics. Jérusalem" , señalando los dos triángulos entre los elementos de la explanada.

Pues bien, el rectángulo de 15 x 16,50 m de la Villa Savoye coincide en sus propiedades con las del bastidor 40F según Ozenfant y Le Corbusier: es posible inscribir en él los dos triángulos equiláteros opuestos. La malla donde va a proyectarse la villa es la misma que aquélla sobre la que se pintan las composiciones puristas ${ }^{4}$.

"Una pintura es la asociación de elementos precisados, asociados, arquitecturados.

Una pintura no debe ser un fragmento, una pintura

the two triangles inverted. If we consider the list of paintings given in Le Corbusier lui-même (Petit, 1970) to be statistically representative, exactly 50 percent (72) of the 144 canvases painted between 1919 and 1930 were in the $40 \mathrm{~F}$ format, measuring $100 \mathrm{~cm}$ x $81 \mathrm{~cm}^{1}$

These proportions, a rectangle with two equilateral triangles drawn inside of them, are the same as those of the various volumes of his Euvres complètes ${ }^{2}$ published since 1929. Le Corbusier had been using them in his architecture since 1915 when, while working at the National Library on what would become his book La construction des villes, he drew the "Parvis dorics. Jérusalem"3 which included two such triangles among the elements of the esplanade. According to Ozenfant and Le Corbusier, the 15 $\mathrm{m} \times 16,5 \mathrm{~m}$ rectangle used in Villa Savoye has the same properties as the $40 \mathrm{~F}$ format frame, so the two opposing equilateral triangles could also be drawn within it. The grid used for designing the Villa project was the same as the one used by the purists in their paintings ${ }^{4}$.

"A painting is the association of purified, associated, architectured elements. es un entero. Un órgano viable es un entero: un órgano viable no es un fragmento.

Para arquitecturar hace falta espacio; el espacio comporta tres dimensiones. Admitimos pues al cuadro, no como una superficie, sino como un espacio" (Ozenfant y Jeanneret, 1921).

$\mathrm{Si}$ admitimos el cuadro como un espacio arquitectonizado, como una articulación de las tres dimensiones, se hace posible admitir, viceversa, el espacio de tres dimensiones como controlable y dirigible desde el plano.

Pero, ¿̇esde qué punto de vista puede justificarse usar un mismo apoyo compositivo para una pintura y una vivienda? El criterio desde el que Jeanneret y Ozenfant escogen el formato $40 \mathrm{~F}$ para sus pinturas está dicho explícitamente: el cuadro debe ser abarcable todo él desde un único punto de vista, sin obligar a dirigir la mirada hacia distintos lados, y debe tener además la neutralidad suficiente para que el reconocimiento del formato no sea previo al de la propia pintura, sino consecuencia de ella. Pero se hace difícil aceptar que eso tenga algo que ver con el trazado a escala en planta de una vivienda, que no parece estar hecha para ser contemplada colgada de una pared. Es más, pueden encontrarse

A painting should not be a fragment, a painting is a whole. A viable organ is a whole: a viable organ is not a fragment.

To architecturate one needs space; space has three dimensions. We therefore recognize a painting not as a surface but as a space" (Ozenfant and Jeanneret, 1921).

If we accept that a painting is an architectured space, an articulation of the three dimensions, we can also accept the reverse: that three-dimensional space is controllable and governable from the plan. But from what point of view can we justify using the same compositional support for a painting as for a house? The criteria used by Jeanneret and Ozenfant for choosing the $40 \mathrm{~F}$ format for their paintings was explicitly stated: one must be able to take in the entire work from one single viewpoint, without having to turn one's eyes in various directions. It must also be sufficiently neutral so that recognition of the format does not come before recognition of the painting itself. However, it is difficult to see how this can be applied to a scale drawing of the plan of a house, which is not intended to be contemplated while hanging on a wall. Furthermore, other comments by Le Corbusier express opposition 

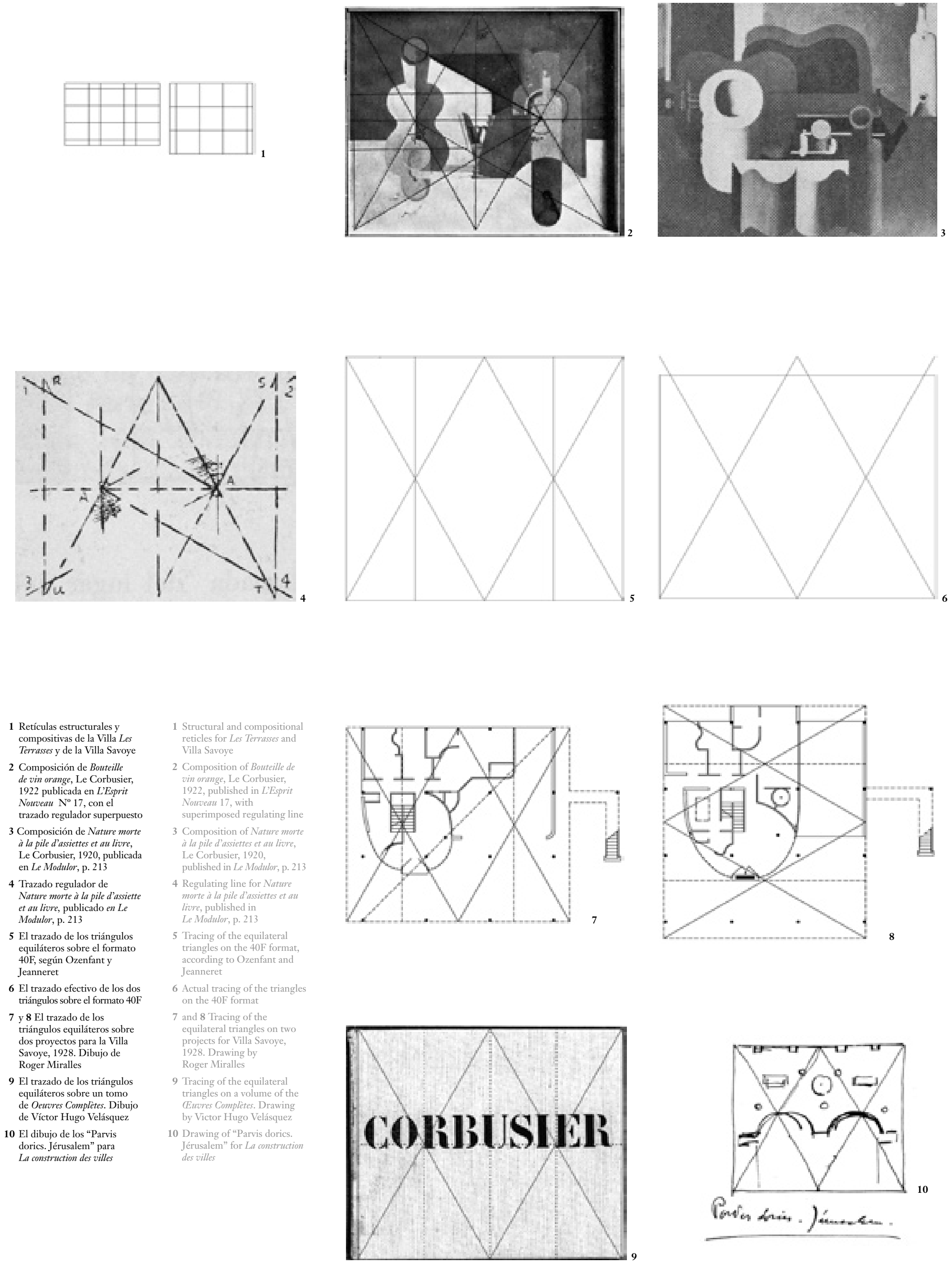


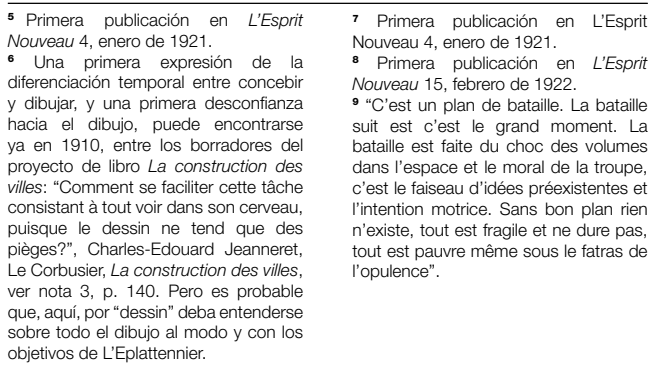

frases de Le Corbusier en contra de la mirada pictórica dirigida hacia las plantas y dibujos de arquitectura. Por ejemplo ésta:

"Una planta no es algo bonito de dibujar, como la cara de una madona; es una austera abstracción; no es más que una algebrización, árida a la mirada"

(Le Corbusier, 1924) ${ }^{5}$.

¿Acaso hay que entender que, si se tratase de cuadros puristas, también ellos austeras abstracciones, áridas algebrizaciones, la comparación entre una planta y una pintura sí que sería en ese caso posible? ¿Dibujar una planta no es como dibujar la cara de una madona, aunque sí es como dibujar un bodegón purista? Pero el propio Le Corbusier se ha encargado de demostrar que pintura purista y pintura bizantina o medieval son iguales, comparten unos mismos principios e instrumentos compositivos: los trazados reguladores son comunes en ambas.

¿Cómo hay que entender, así, esta contradicción en las palabras de Le Corbusier? ¿Cómo leerlas, para que la contraposición desaparezca? ${ }^{36}$ El diverso contexto en que una y otra frase han sido escritas es indicativo, sin duda. Ni siquiera los dos textos están firmados por la misma "persona". Una frase aparece

to a pictorial vision of architectural plans and drawings. For example:

"A plan is not a pretty design like the face of a Madonna; it is an austere abstraction, a mere algebraization arid to the eye" (Le Corbusier, 1924)

Are we to understand by this that if the paintings in question were those of the purists, which were also austere abstractions, arid algebraizations, a comparison between a plan and a painting would in fact be possible? Or that a plan, though not like the face of a Madonna, is indeed similar to a purist still life? It was Le Corbusier himself who took it upon himself to demonstrate that purist and Byzantine or medieval painting are the same, that they share the same compositional principles and instruments, with both having regulating lines.

How then are we to interpret this contradiction in Le Corbusier's arguments? Can we read them in such a way that the inconsistency disappears? ${ }^{6}$ The different contexts in which the two statements were made is no doubt revealing. Indeed, they were not even signed by the same "person". One of them appeared in issue 4 of L'Esprit Nouveau in an article
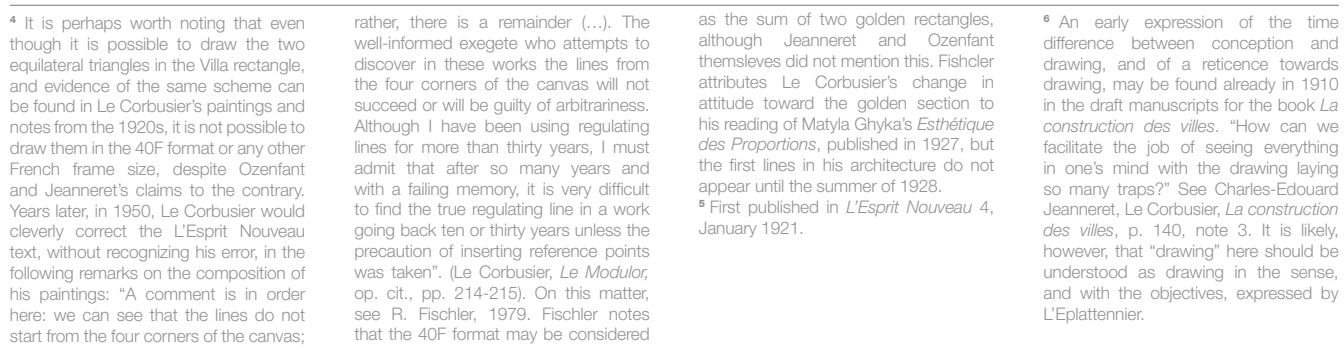

en el número 4 de L'Esprit Nouveau, en un artículo pensado y escrito desde el interior de la pintura, titulado "Le Purisme", firmado por Ozenfant y Jeanneret. La otra frase aparece también en el mismo número de la misma revista, pero está pensada y escrita desde la arquitectura, firmada por alguien llamado Le Corbusier-Saugnier, y se recogerá más tarde en Vers une architecture, donde puede leerse desde entonces.

En dos de los capítulos de Vers une architecture se argumenta acerca de las plantas, en "Trois rappels à MM les architectes. Le plan" (Le Corbusier, 1924) 7 y en "Architecture. L'illusion des plans" (Le Corbusier, 1924) ${ }^{8}$. Le Corbusier, que ha definido la arquitectura como lo que ocurre cuando una mirada humana circula entre específicos hechos plásticos estratégicamente dispuestos, sabe que no hay nada arquitectónico en el trazado y percepción de un dibujo en planta. En "Confession", por ejemplo, escribe:

"Estoy hoy sobrecogido de admiración frente a la belleza primera de una planta de catedral, y de estupor frente a la pobreza primera de la obra misma. La planta y la sección góticas son magnificas, fulgurantes de ingenio. Pero su verificación no llega por el control de los ojos" (Le Corbusier, 1925).
No nos interesa tanto justificar la diferencia de opiniones a partir de situaciones distintas como, a la inversa, entender la base común que se manifiesta en formulaciones aparentemente diversas, pero que deben de ser, bien leídas, coherentes y complementarias entre sí.

Le Corbusier entiende la planta como un ejercicio múltiple. Por un lado, se apoya en el doble sentido que tiene el término plan en francés: equivalente a los castellanos planta y plan. La planta es el plan estratégico para una batalla (Le Corbusier, 1924) ${ }^{9}$, la que se librará entre los efectos plásticos y la mirada del espectador; la planta es la partitura donde los acontecimientos que se producirán en la ejecución arquitectónica efectiva están indicados, con abreviaciones y apuntes convencionales que no coinciden con el momento y la substancia de la percepción. En tanto que plan, la planta es el laboratorio $y$ el escenario donde se ensaya, donde se proyecta, por parte del arquitecto, lo que luego va a ocurrir, tanto durante la construcción como durante la experiencia arquitectónica del espectador. Sólo produciendo orden y determinación en la planta podrá disponerse y garantizarse orden y determinación en la percepción arquitectónica. conceived and written from within the world of painting under the title "Purism", signed by Ozenfant and Jeanneret, while the other, though published in the same issue of the same journal, was conceived and written from an architectural perspective and signed by someone named Le Corbusier-Saugnier, later to be included in Towards a New Architecture.

Arguments regarding ground plans are found in two chapters of Towards a New Architecture: in "Three Reminders to Architects: The Plan" (Le Corbusier, 1924) ${ }^{7}$ and "Architecture. The Illusion of Plans" (Le Corbusier, 1924) ${ }^{8}$. Having defined architecture as what happens when the eye moves among specific, strategically arranged plastic elements, Le Corbusier is aware that there is nothing architectural in the drawing and perception of a plan. In "Confession", for example, he writes:

"Today I am astonished by the singular beauty of the plan of a cathedral, and stupefied by the singular poverty of the work itself. The gothic plan and section are magnificent, sparkling in their ingeniousness, but this cannot be assured through visual examination" (Le Corbusier, 1925)
What is of interest is not to justify the difference of opinions by claiming different situations so much as the contrary - to see the common basis in these apparently diverse formulations that, if read carefully, should in fact be both consistent and complementary.

Le Corbusier interprets the plan as a multiple exercise. On the one hand, he makes use of the double meaning attached to the word. Thus, it can be the strategic plan of a battle (Le Corbusier, 1924) $)^{9}$ between plastic effects and the spectator's gaze, the musical score indicating what will happen and its actual architectural execution, with abbreviations and conventional signs that do not coincide with either the moment or the substance of perception. And it can also be the laboratory and scenario where the architect rehearses and plans what is going to happen during both construction and the spectator's architectural experience. Only if there is order and decision in the plan can order and decision be ensured in the architectural perception.

"The plan is the basis. Without a plan, there can be no grandeur of intention and expression, no rhythm, no volume, no coherence. Without a plan, there 

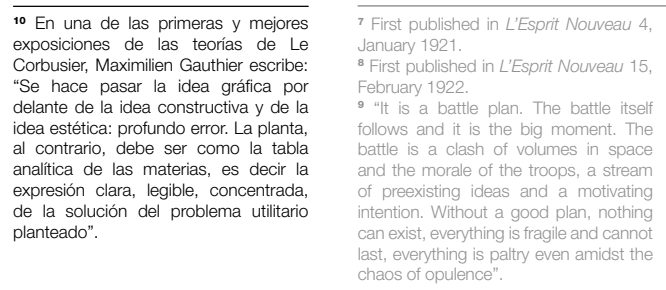

"La planta está en la base. Sin planta, no hay ni grandeza de intención ni de expresión, ni ritmo, ni volumen, ni coherencia. Sin planta lo que bay es esa sensación insoportable para el hombre, informe, indigente, desordenada, arbitraria.

La planta exige la imaginación más activa. Exige también la disciplina más severa. La planta es la determinación de todo; es el momento decisivo. Una planta no es bonita de dibujar, como la cara de una madona; es una austera abstracción; no es más que una algebrización árida para la mirada. (...)

La planta lleva en sí un ritmo primario determinado: la obra se desarrolla en extensión y en altura, siguiendo sus prescripciones, con consecuencias que se extienden desde lo más simple basta lo más complejo, bajo una misma ley. La unidad de la ley es la ley de la buena planta: ley infinitamente modulable.

El ritmo es un estado de equilibrio que procede de simetrias simples o complejas, o que procede de sabias compensaciones. El ritmo es una ecuación. (...)

La planta lleva en sí la esencia misma de la sensación" (Le Corbusier, 1924).

"Hacer una planta es precisar, fijar ideas.

Es haber tenido ideas.

Es ordenar esas ideas para que se vuelvan inteligibles, ejecutables y transmisibles. Hay pues que manifestar

is a sensation unbearable to man of shapelessness, destitution, disorder, arbitrariness.

The plan requires a bigbly active imagination. It also requires the strictest discipline. It determines everything; it is the decisive moment. A plan is not a pretty design like the face of a Madonna; it is an austere abstraction, a mere algebraization arid to the eye. (...) The plan carries within it a primary rhythm: the work develops in extension and height, following its prescriptions with consequences that range from the very simple to the highly complex under the same law. The unity of the law is the law of a good plan: a law that is infinitely modulatable.

The rbythm is a state of equilibrium that proceeds from simple or complex symmetries or from erudite compensations. The rhythm is an equation. (...).

The plan carries within it the very essence of the sensation" (Le Corbusier, 1924).

"To draw a plan is to specify, to establish ideas.

It is to have had ideas.

It is to organize those ideas so that they become intelligible, executable and transmittable. One must therefore manifest a specific intention, one must have had ideas in order to have formed an intention. A plan is in some sense a concentrate, like a table of una intención precisa, haber tenido ideas, para baber podido darse una intención. Una planta es, de alguna manera, un concentrado, como una tabla analítica de materias. Bajo una forma tan concentrada que aparece como un cristal, como un dibujo de geometría, contiene una enorme cantidad de ideas y una intención motriz" (Le Corbusier, 1924) ${ }^{10}$.

Pero hay otro aspecto propio de la planta. Si lo arquitectónico es, específicamente, lo que ocurre cuando el espectador se enfrenta a hechos plásticos sabiamente dispuestos, eso significa que lo dibujado en planta no puede ser confundido con lo arquitectónico, pero ni siquiera lo construido coincide por entero con lo arquitectónico: el edificio es, también él, un medio instrumental, distinto a las sensaciones fisiológicas impuestas y a las libres asociaciones de ideas que ocurren en los sentidos y cabeza del espectador, cuyo dispositivo integrado forma, él sí, lo específicamente arquitectónico. No hay representación posible de lo arquitectónico, que es algo que ocurre en un circuito virtual entre el objeto plástico y la mirada y cabeza del espectador, donde el espectador usa plenamente, libremente, individualmente sus capacidades propias de memoria, análisis, razonamiento, creación.
"La arquitectura, que es asunto de emoción plástica, debe, en su dominio, EMPEZAR TAMBIÉN POR EL PRINCIPIO, y USAR LOS ELEMENTOS SUSCEPTIBLES DE CAPTAR NUESTROS SENTIDOS, DE COLMAR NUESTROS DESEOS VISUALES, y de disponerlos de manera tal QUE SU VISTA NOS AFECTE CLARAMENTE, por la finura o la brutalidad, el tumulto o la serenidad, la indiferencia o el interés; estos elementos son elementos plásticos, formas que nuestros ojos ven claramente, que nuestro espiritu mide. Estas formas primarias o sutiles, flexibles o brutales, actúan fisiológicamente sobre nuestros sentidos (esfera, cubo, cilindro, horizontal, vertical, oblicua, etc.) y los conmueven. Al quedar afectados, somos capaces de percibir más allá de las sensaciones brutales; nacerán entonces algunas relaciones, que actúan sobre nuestra consciencia y nos ponen en estado de gozo (consonante con las leyes del universo que nos dirigen y a las cuales se someten todos nuestros actos), donde el hombre usa plenamente sus dotes de recuerdo, de examen, de razonamiento, de creación" (Le Corbusier, 1924).

De lo arquitectónico, así, fuera de la experiencia directa, sólo poseemos rastros incompletos, reducciones, secciones, sombras, reflejos en otras dimensiones, que son índice de lo arquitectónico pero que ni lo representan ni coinciden con ello. El edificio construido es uno de tales reflejos, los contents. In such a concentrated form that it looks like a crystal or a geometric drawing, it contains an enormous quantity of ideas and a motivating intention" (Le Corbusier, 1924) ${ }^{10}$.

But there is another aspect of the plan. If the architectural is what occurs when the spectator is confronted with plastic elements intelligently arranged, what is drawn in the plan cannot be considered architectural. But not even what is built coincides completely with the architectural. The building, too, is an instrumental medium, distinct from the physiological sensations and free associations of ideas experienced by the senses and in the mind of the spectator, whose powers of integration is what forms the specifically architectural. No representation of the architectural is possible, for it is something that occurs in the virtual circuit between plastic object and the eye and mind of the spectator, who fully and freely uses each of his or her own capacities for memory, analysis, reason and creation.

"Architecture, a thing of plastic emotion, must, in its domain, BEGIN AT THE BEGINNING AS WELL, AND USE ELEMENTS CAPABLE OF STIMULATING OUR
SENSES AND FULFILLING OUR VISUAL DESIRES. It must arrange those elements in such a way that SEEING THEM CLEARLY AFFECTS US by their refinement or brutality, tumultuousness or serenity, indifference or interest. They are plastic elements, forms that our eyes see clearly, that our spirit takes the measure of. Primary or subtle, supple or brutal, these forms act physiologically upon our senses (sphere, cube, cylinder, horizontal, vertical, oblique, etc.) and shake them up. Thus affected, we are able to perceive beyond brutal sensations. Certain connections are made that act upon our conscience and transport us into a state of enjoyment (consonant with the laws of the universe that govern us and to which all of our acts are subject), in which man makes full use of his gifts of memory, examination, reason and creation" (Le Corbusier, 1924).

Other than through direct experience, we possess only incomplete traces, reductions, sections, shadows and reflections in other dimensions of the architectural. They are indices of it, but neither represent nor coincide with it. A finished building is such a reflection, as are the plan drawings. If the architectural sentiment is possible, it is so for Le Corbusier on the basis of natural laws that are common to both the 
y el negativo de la experiencia de habitar. En una simplificación, probablemente excesiva, la educación arquitectónica podría reducirse a la generación de la capacidad para pasar lo más rápidamente posible -si es posible en forma instantánea- desde ese negativo a ese positivo. Esto es, ser capaces de ver la abstracción del plano como cifra de una determinada situación arquitectónica y ver las situaciones del habitar como susceptibles de ser cifradas en un plano. En ello se juega una parte muy importante de la abstracción arquitectónica y el rol de la planta es, casi siempre, fundamental.

\section{Planta y plantas}

La planta ha tenido mala prensa durante buena parte del siglo veinte. Se ha puesto frecuentemente en duda su capacidad para representar apropiadamente el fenómeno arquitectónico. Un corte horizontal trazado a una determinada altura de un edificio no parecía capaz de representar los sutiles fenómenos del espacio. Para ello, se requería el croquis, la perspectiva, la fotografía. Bruno Zevi ${ }^{1}$ llegó a pensar que sólo el cine podía aproximarse a la experiencia arquitectónica. El dialéctico Le Corbusier le dedicó a la planta dos capítulos en su capital Vers une Architecture. En uno de ellos, "La ilusión de los planes" ${ }^{2}$ ataca su cosificación gráfica por parte de la tradición de Beaux Arts "gráficos de estrellas resplandecientes que provocan una ilusión óptica. La estrella más hermosa se convierte en el gran premio de Roma". En otro, "El plan", señala: "el plan es el generador... el plan está en la base"3. Anverso y reverso; éste es el peligroso filo sobre el cual la realidad de la planta parece moverse: abstracción vacía o abstracción generadora. Aparentemente, este delicado instrumento, del que difícilmente pueden prescindir arquitectos y constructores, sin una adecuada conexión con la experiencia arquitectónica se desliza hacia una abstracción vacía. Entendido en cambio como generadora de la idea arquitectónica se acerca a su acepción biológica: la planta como vegetal, una entidad con capacidad de crecimiento.

\section{Planta y coreografía}

Goethe, siempre sorprendente, discutió en alguna ocasión el carácter predominantemente visual de la arquitectura. Sostenía, en cambio, que ella debería trabajar para el sentido del movimiento del cuerpo humano. El resultado de esta actitud sería, que alguien conducido con los ojos vendados a través de una casa muy bien construida, experimentaría una sensación similar a aquella que se experimenta cuando se danza. Dejándonos guiar por esta penetrante observación de Goethe, una planta podría verse como teniendo mucho en común con una notación coreográfica. La planta, asî concebida, nos señala en simultáneo el orden de los movimientos necesarios para construir y el de los movimientos posibles dentro de lo construido. Su relación con la experiencia arquitectónica aparece así más como una relación rítmica que como una relación visual. Entender las cosas de este modo permitiría, de paso, resolver un problema que pareció desvelar a Le Corbusier. A pesar de existir evidencias ciertas de que el maestro utilizaba trazados reguladores al ajustar la geometría de sus plantas, sólo se mostraba dispuesto a aceptar su utilización en fachada. Al no ser la de la planta una experiencia visual, parecía un mero formalismo la utilización en ella de trazados reguladores. Sin embargo, si entendiéramos la geometría en su vertiente de potencial notación rítmica, tal contradicción no existiría y podríamos ver la planta como la realidad tras la fachada. ARe

Bibliografía: Le Corbusier; Hacia Una Arquitectura. Editorial Poseidón, Buenos Aires, 1978. / Suárez, Isidro; Organización Filosofía y Lógica de la Programación Arquitectural. Escuela de Arquitectura de la Universidad Católica de Chile. Ver T. I, Lección 10. / Zevi, Bruno; Saber Ver la Arquitectura. Editorial Poseidón, Buenos Aires, 1951. a positive of the experience of construction and the negative of the experience of inhabiting. At the risk of oversimplifying, we could sum up architectural training as creating the ability to move as quickly as possible from the positive to the negative. Or to be able to see the plan in abstract terms as the code for a given architectural situation, and see habitational situations as capable of being codified in a plan. Much of architectural abstraction occurs in this manner, and the role of the ground plan is almost always fundamental.

\section{Plan, plans and plants}

Ground plans have had a bad press for most of the last century. Their ability to adequately represent the architectural phenomenon has frequently been called into question. A horizontal section did not seem to represent the subtleties of space; what was needed was a sketch, a perspective drawing or photograph. Bruno Zevi ${ }^{1}$ went so far as to conclude that only cinema could approximate a true architectural experience. The dialectician Le Corbusier devoted two chapters to architectural plans in his fundamental work, Towards a New Architecture. In one, "The Illusion of Plans", ${ }^{2}$ he attacks their graphic reification by the Ecole des Beaux Arts tradition of "making graphic representations of star-patterns, creating an optical illusion. The most beautiful star becomes the Grand Prix de Rome." In the chapter entitled simply "Plan" he states: "the plan is the generator... the plan is in the base". ${ }^{3}$ Obverse and reverse: this is the dangerous knife-edge on which the reality of the plan would seem to move. Empty abstraction or an abstraction that generates. Apparently, this delicate instrument that architects and builders cannot do without falls into empty abstraction if it doesn't have a solid connection with architectural experience. If understood as a generator of the architectural idea, the plan is more closely approximates its biological definition as expressed in the Spanish term for it: planta, which also translates the English word "plant", an entity with the ability to grow.

\section{Ground plan and choreography}

Goethe, ever surprising, once talked about architecture's predominantly visual character. But he also maintained that architecture should work in harmony with the human body's sense of movement. A person who was led blindfolded through a well-constructed house would thus experience a sensation similar to what one experiences when dancing: a plan could be seen to have much in common with choreography notation. Thus conceived, a plan would show us simultaneously the order of movements required to construct and the movements that are possible within what is constructed. The plan's relationship to the architectural experience would appear more rhythmical than visual. We may note that this manner of understanding things would solve a problem that apparently kept Le Corbusier awake at night. Although there is some evidence that the great master employed regulating lines for his plans, he was only willing to accept their use for façades. Since a plan was not a visual experience, using regulating lines in it seemed a mere formalism. Nevertheless, if we consider geometry's potential as a rhythmic notation, this contradiction disappears and we may see the plan as the reality behind the façade. ARQ

Bibliography: Le Corbusier; Hacia Una Arquitectura. Editorial Poseidón, Buenos Aires, 1978. / Suárez, Isidro; Organización Filosofía y Lógica de la Programación Arquitectural. Escuela de Arquitectura de la Universidad Católica de Chile. Re. T. I, Lección 10. / Zevi, Bruno Architecture as Space: How to Look at Architecture. Da Capo Press, New York, 1993. 